TITLE:

\title{
Enzymatic synthesis of chiral amino acid sulfoxides by Fe(II)/a- ketoglutarate-dependent dioxygenase
}

\section{AUTHOR(S):}

Hibi, Makoto; Kawashima, Takashi; Yajima, Hiroko; Smirnov, Sergey V.; Kodera, Tomohiro; Sugiyama, Masakazu; Shimizu, Sakayu; Yokozeki, Kenzo; Ogawa, Jun

\section{CITATION:}

Hibi, Makoto ... [et al]. Enzymatic synthesis of chiral amino acid sulfoxides by Fe(II)/a-ketoglutarate-dependent dioxygenase. Tetrahedron: Asymmetry 2013, 24(17): 990-994

\section{ISSUE DATE:}

2013-09

URL:

http://hdl.handle.net/2433/178735

\section{RIGHT:}

(c) 2013 Elsevier Ltd.; この論文は出版社版でありません。引用の際には 出版社版をご確認ご利用ください。; This is not the published version. Please cite only the published version. 


\section{Enzymatic synthesis of chiral amino acid sulfoxides by}

\section{$2 \mathrm{Fe}(\mathrm{II}) / \alpha$-ketoglutarate-dependent dioxygenase}

3

4 Makoto Hibi $^{\mathrm{a}}$, Takashi Kawashima ${ }^{\mathrm{b}}$, Hiroko Yajima ${ }^{\mathrm{b}}$, Sergey V. Smirnov ${ }^{\mathrm{c}}$, Tomohiro Kodera ${ }^{\mathrm{d}}$,

5 Masakazu Sugiyama ${ }^{\mathrm{e}}$, Sakayu Shimizu ${ }^{\mathrm{b}}$, Kenzo Yokozeki ${ }^{\mathrm{a}, \mathrm{e}}$, Jun Ogawa, $^{\mathrm{b}, *}$

6

$7 \quad{ }^{\mathrm{a}}$ Industrial Microbiology and ${ }^{\mathrm{b}}$ Division of Applied Life Sciences, Graduate School of

8 Agriculture, Kyoto University, Kitashirakawa-oiwakecho, Sakyo-ku, Kyoto, 606-8502, Japan

9 'Ajinomoto-Genetika Research Institute, 1st Dorozhny pr. 1, Moscow 113545, Russia

$10{ }^{\mathrm{d}}$ Institute of Food Sciences \& Technologies Food Product Division and ${ }^{e}$ Research Institute for

11 Bioscience Products \& Fine Chemicals, Ajinomoto Co., Inc., Suzuki-cho, Kawasaki-ku,

12 Kawasaki 210-8681, Japan

13

14

15

$16 *$ *orresponding author. Fax.: +8175753 6128 .

17 E-mail address: ogawa@kais.kyoto-u.ac.jp (J. Ogawa). 


\section{Abstract}

2 Asymmetric sulfoxidation of sulfur-containing L-amino acid was successfully achieved

3 through bioconversion using IDO, which is an $\mathrm{Fe}(\mathrm{II}) / \alpha$-ketoglutarate-dependent dioxygenase

4 previously found in Bacillus thuringiensis strain 2e2. IDO catalyzed sulfoxidation of

5 L-methionine, L-ethionine, $S$-methyl-L-cysteine, $S$-ethyl-L-cysteine, and $S$-allyl-L-cysteine

6 into corresponding (S)-configured sulfoxides such as (+)-methiin and (+)-alliin, which are

7 responsible for valuable physiological activities in mammals, and have high stereoselectivity.

8 Here, we established an effective preparative laboratory scale production method to obtain

9 optically pure chiral sulfoxides using an IDO biocatalyst.

10 


\section{$1 \quad 1$. Introduction}

2

Chiral sulfoxides are noteworthy reagents in a wide range of industrial fields. They

3 have been used as chiral building blocks and chiral auxiliaries in the organic synthesis of

4 other optically active compounds. ${ }^{1}$ In the medicinal and pharmaceutical industry, chiral

5 sulfoxide derivatives are of special importance because of their high biological activity. ${ }^{2}$

6 Also, chiral sulfinyl groups occur naturally in some functionalized amino acids, including

7 L-methionine $(S)$-sulfoxide [(+)-MetSO] in the methionine metabolism of mammals ${ }^{3}$ and

8 L-cysteine-related sulfoxides found in Allium and Brassica species. ${ }^{4,5}$ In particular,

$9 \quad S$-methyl-L-cysteine $(S)$-sulfoxide [(+)-methiin] and $S$-allyl-L-cysteine $(S)$-sulfoxide

$10[(+)$-alliin $]$ are promising materials for use in functional foods or drugs since they have

11 antibiotic, ${ }^{6}$ antioxidant, ${ }^{7,8}$ anti-inflamatory, ${ }^{9}$ anti-diabetic, ${ }^{10,11}$ anti-Alzheimer's, ${ }^{12}$ and

12 anti-cholesterolemic ${ }^{13}$ effects. Also, $S$-ethyl-L-cysteine $(S)$-sulfoxide[(+)-ethiin] is known

13 to be a minor flavor precursor in Allium species. ${ }^{14}$

14 To date, many production methods for chiral sulfoxides have been established using

15 chemical and biological catalysts. ${ }^{15}$ In particular, biocatalytic oxidation of prochiral sulfides

16 is an advantageous method because of the highly stereoselective and chemoselective

17 properties of oxidizing enzymes such as monooxygenases, dioxygenases, and peroxidases.

16-18 A cyclohexanone monooxygenase of Acinetobacter calcoaceticus ${ }^{19}$ and

19 flavin-containing monooxygenases (FMOs) in mammalian microsomes ${ }^{20-22}$ are known to

20 promote sulfoxidation activity in sulfur-containing amino acids.

Previously, we found that an $\mathrm{Fe}(\mathrm{II}) / \alpha$-ketoglutarate-dependent dioxygenase (IDO)

22 from Bacillus thuringiensis strain 2e2 catalyzed hydroxylation of L-isoleucine into

$23(2 S, 3 R, 4 S)$-4-hydroxyisoleucine. ${ }^{23,24}$ In addition to stereoselective hydroxylation, IDO also

24 catalyzed stereoselective sulfoxidation of L-methionine and L-ethionine. ${ }^{25}$

25 In this study, we also found that IDO catalyzed asymmetric oxidation of several 
1 other sulfur-containing L-amino acids with high yield. Furthermore, we demonstrated dried

2 microbial cells containing IDO (IDO-catalyst) was useful to apply to the preparative

3 laboratory scale production of valuable chiral sulfoxides such as (+)-MetSO, (+)-methiin,

4 (+)-ethiin, and (+)-alliin.

5 


\section{2. Results and Discussion}

2

\section{2.1. Conversion of sulfur-containing L-amino acids}

We investigated the IDO-catalyzed oxidation of multiple sulfur-containing

5 L-amino acids (Table 1). The dried cell powder of IDO-expressing E. coli

6 (IDO-catalyst) was used as a biocatalyst for oxidation. IDO-catalyst converted several

$7 \quad S$-alkyl-L-homocysteins like L-methionine (Met) and L-ethionine (Eth) and several

$8 S$-alkyl-L-cysteines, such as $S$-methyl-L-cysteine (SMCys), $S$-ethyl-L-cysteine (SECys), 9 and S-allyl-L-cysteine (SACys), of which Met, SMCys, SECys, and SACys were better

10 substrates of IDO-catalyst (complete conversion of $10 \mathrm{mM}$ substrate in most cases).

11 IDO-catalyst conversion of Eth, which had a longer alkyl chain than Met, was somewhat less (67\% conversion). IDO-catalyst showed $0.064 \mu \mathrm{mol} / \mathrm{min} / \mathrm{mg}(\mathrm{U} / \mathrm{mg})$ of

13 specific activity when Met was used as a substrate. On the other hand, the purified

14 IDO enzyme, which was prepared as previously reported, ${ }^{25}$ showed $0.30 \mathrm{U} / \mathrm{mg}$ of the

15 specific activity to Met. From these results, it was estimated that IDO-catalyst

16 contained approximately $20 \%$ (w/w) of active form of IDO enzyme. The product of IDO-catalyst in the reaction mixture with Met was analyzed with the 1-fluoro-2-4-dinitrophenyl-5-L-alanine amide (FDAA) method for HPLC analysis and compared with the elution order of $( \pm)$-MetSO reported previously. ${ }^{26}$ The

20 product was then determined to be L-methionine $(S)$-sulfoxide [(+)-MetSO], as shown

21 in Figure 1a and had $>99 \%$ diastereomer excess $(d e)$. Similarly, the product with Eth

22 was analyzed using the FDAA method and determined to have $>99 \%$ de. According to

23 the published data on L-ethionine sulfoxides in optical rotation and NMR

24 measurements, ${ }^{27}$ the reaction product was determined to be L-ethionine $(S)$-sulfoxide 
1 [(+)-EthSO], as shown in Figure 1a. In order to identify the products of IDO-catalyst

2 in the reaction mixtures with $S$-alkyl-L-cysteines such as SMCys, SECys, and SACys,

3 they were analyzed with dansylchloride (Dns-Cl) methods for HPLC analysis and

4 compared with the elution orders of $( \pm)$-methiin, $( \pm)$-ethiin, and $( \pm)$-alliin reported

5 previously $^{28}$. IDO-catalyst was thereby explained to convert SMCys, SECys, and

6 SACys into $S$-methyl-L-cysteine $(S)$-sulfoxide [(+)-methiin], $S$-ethyl-L-cysteine

7 (S)-sulfoxide [(+)-ethiin], and $S$-allyl-L-cysteine $(S)$-sulfoxide [(+)-alliin], respectively

8 (Figure 1b). Thus, IDO-catalyst catalyzed $(S)$-specific sulfoxidation of various

9 sulfur-containing L-amino acids. The stereoselectivity in the formations of these $10 S$-alkyl-L-cysteine sulfoxides was $88 \% d e, 91 \% d e$, and $83 \%$ de, respectively. These

$11 d e$ values were lower than those of $S$-alkyl-L-homocysteine sulfoxides. These

12 differences in de values are caused by the relative position of the sulfur atom in amino

13 acid molecules. IDO-catalyzed oxidation proceeded more stereospecifically using

14 amino acids with a sulfur atom at the $\delta$-position than those at the $\gamma$-position. It was

15 inconsistent with our previous observation that IDO catalyzed absolutely stereoselective

$16 \gamma$-hydroxylation of some L-amino acids. ${ }^{25}$

2.2. Effects of pH and temperature on activities and stabilities of IDO-catalyst

Thus, IDO-catalyst is a good biocatalyst for asymmetric synthesis of chiral

20 sulfoxides. In order to identify the best conditions for the biocatalysis, the $\mathrm{pH}$ and

21 temperature profiles of the IDO-catalyst were determined using the (+)-alliin as a

22 representative product (Figure 2). IDO-catalyst showed a $\mathrm{pH}$ optimum between 6.0

23 and 7.0, and retained over $90 \%$ activity after 1 h-incubation at $\mathrm{pH} 7.0$ to 9.0 (Figure $2 \mathrm{a}$ ).

24 Also, IDO-catalyst showed a temperature optimum at $28^{\circ} \mathrm{C}$, and retained over $80 \%$ 
1 activity after 1 h-incubation at 20 to $28^{\circ} \mathrm{C}$ (Figure $2 \mathrm{~b}$ ). From these results, the best

2 conditions for the bioconversion were set at $\mathrm{pH} 7.0$ and $28^{\circ} \mathrm{C}$. So, it was found that

3 IDO catalyzed two different oxidations of amino acids, sulfoxidation and hydroxylation,

4 under the similar reaction conditions. ${ }^{23}$

5

6 2.3. Preparative laboratory scale productions of chiral amino acid sulfoxides

7 The preparative laboratory scale productions of (+)-MetSO, (+)-methiin,

8 (+)-ethiin, and (+)-alliin from L-amino acids were carried out under optimal conditions.

9 As shown in Figure 3, each product was formed from $50 \mathrm{mM}$ of substrate for $4 \mathrm{~h}$,

10 resulting in an almost stoichiometric conversion of L-amino acid substrates to products.

11 Among them, Met was the best substrate of IDO-catalyst and $47 \mathrm{mM}$ of (+)-MetSO was

12 produced from $50 \mathrm{mM}$ of Met (94\% yield with $>99 \%$ de) in the 4-h reaction (Table 2).

13 Estimated total turnover number of IDO enzyme included in IDO-catalyst used was

14 1,342 during this conversion. Also, SMCys and SECys were linearly converted into

15 (+)-methiin and (+)-ethiin, and then the product amount reached $32 \mathrm{mM}(64 \%$ yield

16 with $93 \%$ de) and $43 \mathrm{mM}(86 \%$ yield with $95 \%$ de) in the reaction, respectively. In

17 particular, (+)-ethiin content is very low in the tissue of Allium species ${ }^{29}$ and its own

18 function has not been defined yet. It was expected that (+)-ethiin also have valuable

19 physiological properties as well as (+)-methiin and (+)-alliin. In contrast, the

20 conversion of SACys proceeded linearly until $2 \mathrm{~h}$ but weakened after $2 \mathrm{~h}$, and then only

$2135 \mathrm{mM}$ of (+)-alliin was produced (70\% yield with $81 \%$ de). A high concentration of

22 (+)-alliin (about $>30 \mathrm{mM}$ ) may have inhibited the sulfoxidation activity of IDO-catalyst.

\section{3. Conclusion}


1 Asymmetric oxidation of sulfur-containing L-amino acid with IDO-catalyst

2 proved a very efficient way to produce various chiral amino acid sulfoxides, including

3 (+)-methiin and (+)-alliin, which show noteworthy physiological activities in mammals.

4 The dried cell powder of IDO-expressing E. coli was a handy biocatalyst because it was

5 sufficiently stable to sustain the oxidation activity for several hours. With our method

6 established in this study, preparative laboratory scale productions of chiral sulfoxides

7 with high optical purity could easily be provided through bioconversion, allowing

8 further to development of their industrial applications.

\section{Experimental Section}

\subsection{General Information}

All reagents and solvents were as obtained by commercial source. Reactions

14 were monitored by thin-layer chromatography (TLC) which was performed with

15 Kieselgel $60 \mathrm{~F}_{254}$ plates (Merck, NJ, USA) and visualized using ninhydrin staining. $\quad{ }^{1} \mathrm{H}$

16 NMR and ${ }^{13} \mathrm{C}$ NMR were recorded on an Avance 500 (BrukerBioSpin, MA, USA).

$17 \mathrm{D}_{2} \mathrm{O}$ solutions were used for ${ }^{1} \mathrm{H}$ NMR analysis. $\mathrm{D}_{2} \mathrm{O}$ solutions containing acetone as 18 an internal standard were used for ${ }^{13} \mathrm{C}$ NMR analysis. Chemical shifts are reported in 19 parts per million (ppm, $\delta)$ relative to residual solvent signals $\left(\mathrm{H}_{2} \mathrm{O}, \delta 4.79\right)$ or relative to 20 acetone ( $\delta 30.89)$. Coupling constants ( $J$ values) are given in $\mathrm{Hz}$, and peak

21 multiplicities are denoted by s (singlet), d (doublet), dd (doublet of doublets), $\mathrm{m}$

22 (multiplet), and t (triplet). Optical rotation was measured with a JASCO DIP-370

23 spectrometer. 


\section{4.2. Chemicals}

$( \pm)-M e t S O$ was purchased from Sigma-Aldrich (St. Louis, USA), and ( \pm )-alliin and ( \pm )-methiin were purchased from LKT Laboratories, Inc. (St. Paul, USA). In order to obtain $( \pm)$-EthSO and $( \pm)$-ethiin, Eth and SECys were oxidized in $30 \%(\mathrm{w} / \mathrm{w})$ hydrogen peroxide for $24 \mathrm{~h}$ and hand dried under reduced pressure, respectively.

\subsection{Recombinant Bacterial Strain and Preparation of IDO-Catalyst}

Escherichia coli Rosetta 2 (DE3) carrying pET-IDO (2e2) was used for enzyme expression. ${ }^{25}$ Recombinant E. coli cells were grown aerobically at $37^{\circ} \mathrm{C}$ and $300 \mathrm{rpm}$ in $250 \mathrm{~mL} \mathrm{LB}$ medium with ampicillin $(50 \mu \mathrm{g} / \mathrm{ml})$ and chloramphenicol $(34 \mu \mathrm{g} / \mathrm{ml})$.

At an OD $600=1.0$, isopropyl- $\beta$-D-thiogalactopyranoside (IPTG) was added to a final concentration of $1 \mathrm{mM}$, and the cultures were incubated for $16 \mathrm{~h}$ at $28^{\circ} \mathrm{C}$ and $300 \mathrm{rpm}$. The cells were harvested by centrifugation $\left(8000 \times g, 30 \mathrm{~min}, 4^{\circ} \mathrm{C}\right)$ and washed in physiological saline twice. The cell pellet was air-dried, dehydrated using silica gel, and pounded in a mortar to obtain dried cell powder as IDO-catalyst.

\subsection{Derivatization and HPLC Assay}

Amino acids were analyzed by HPLC after derivatization with 1-fluoro-2-4-dinitrophenyl-5-L-alanine amide (FDAA) ${ }^{26}$ or dansylchloride (Dns-Cl) ${ }^{28}$ For the FDAA method, the derivatives were prepared by mixing $30 \mu \mathrm{l}$ of the sample solution, $50 \mu \mathrm{l}$ of $1 \%$ FDAA in acetone, and $10 \mu \mathrm{l}$ of $1 \mathrm{M}$ sodium bicarbonate. The reaction mixture was heated at $40^{\circ} \mathrm{C}$ for $1 \mathrm{~h}$, and then $5 \mu \mathrm{l}$ of $2 \mathrm{M} \mathrm{HCl}$ was added. The derivatized products were analyzed by HPLC. HPLC analysis was performed with a Waters Alliance 2695 HPLC System (Waters, Milford, USA) equipped with a Beckman 
1 Ultrasphere ODS column $(5 \mu \mathrm{m}, 250 \times 4.6 \mathrm{~mm}$, HiChrom, Reading, UK) and

2 maintained at $40^{\circ} \mathrm{C}$. For analysis, $50 \mathrm{mM}$ triethylamine phosphate (solvent A) and

3 acetonitrile (solvent $\mathrm{B}$ ) were used as the mobile phase, with a flow rate of $1 \mathrm{ml} / \mathrm{min}$, the

4 gradient of solvent B: 0-15 min: $15 \%$; $15-30 \mathrm{~min}: 15 \%-22 \%$; 30-33 min: $22-40 \%$; 33-40

5 min: 40\%; 40-43 min: 40-15\%; 43-47 min: 15\%, and detection wavelength of $360 \mathrm{~nm}$.

6 The retention times of (+)-MetSO, (-)-MetSO, (+)-EthSO, and (-)-EthSO were 17.0,

7 18.0, 22.1, and $23.4 \mathrm{~min}$, respectively. For the Dns-Cl method, the derivatives were

8 prepared by mixing $100 \mu \mathrm{l}$ of the sample solution, $250 \mu \mathrm{l}$ of $10 \mathrm{mM} \mathrm{Dns}-\mathrm{Cl}$ in

9 acetonitrile, and $0.65 \mathrm{ml}$ of a $20 \mathrm{mM}$ borate buffer ( $\mathrm{pH} 9.2$ ). The mixture was briefly

10 shaken, allowed to stand at room temperature for $15 \mathrm{~min}$, filtered through a $0.45 \mu \mathrm{m}$

11 nylon filter, and analyzed by HPLC. HPLC analysis was performed with a Waters

12 Alliance 2695 HPLC System equipped with a Varian Microsorb MV C18 column (5 $\mu$, $13250 \times 4.6 \mathrm{~mm}$, Agilent Technologies, Santa Clara, USA) and maintained at $40^{\circ} \mathrm{C}$. For 14 analysis, $50 \mathrm{mM}$ sodium acetate buffer ( $\mathrm{pH}$ 5.0, solvent $\mathrm{A}$ ) and methanol (solvent $\mathrm{B}$ )

15 were used as the mobile phase, with a flow rate of $0.9 \mathrm{ml} / \mathrm{min}$. The gradient of solvent

16 B is as follows: 0-35 $\mathrm{min}, 30 \%-40 \%$; 35-60 $\mathrm{min}, 40 \%-75 \%$; 60-65 $\mathrm{min}, 75 \%$; $65-70 \mathrm{~min}$,

$1730 \%$; and a detection wavelength of $250 \mathrm{~nm}$. The retention times of (-)-methiin,

18 (+)-methiin, (-)-ethiin, (+)-ethiin, (-)-alliin, and (+)-alliin were 20.7, 25.5, 25.9, 31.5,

1931.5 , and $38.9 \mathrm{~min}$, respectively.

20

21 4.5. Bioconversion of Sulfur-Containing Amino Acids with IDO-catalyst

IDO-catalyst was used for bioconversion of sulfur-containing amino acids.

23 The standard reaction mixture contained $10 \mathrm{mM}$ substrate, $15 \mathrm{mM} \alpha$-ketoglutarate, 0.5

$24 \mathrm{mM} \mathrm{FeSO}_{4} \cdot 7 \mathrm{H}_{2} \mathrm{O}, 2 \mathrm{mM}$ ascorbate, $1 \mathrm{mM} \mathrm{DTT}$, and $2 \mathrm{mg} / \mathrm{ml}(0.13 \mathrm{U} / \mathrm{ml})$ IDO-catalyst 
1 described above in $1 \mathrm{ml}$ of a $50 \mathrm{mM}$ Bis-Tris/HCl buffer $(\mathrm{pH}$ 6.0). For the

2 bioconversion of sulfur-containing amino acids, the mixture was slightly shaken at $28^{\circ} \mathrm{C}$

3 for $16 \mathrm{~h}$. The effects of $\mathrm{pH}$ on the activity were measured in the standard reaction

4 mixture using SACys as a substrate at $28^{\circ} \mathrm{C}$ for $30 \mathrm{~min}$, except $150 \mathrm{mM}$ GTA buffer (50

$5 \mathrm{mM}$ 3,3-dimethylglutaric acid, $50 \mathrm{mM}$ Tris/HCl, $50 \mathrm{mM}$

6 2-amino-2-methyl-1,3-propanediol, $\mathrm{pH} 4$-10) was used instead of Bis-Tris/HCl buffer.

7 The $\mathrm{pH}$ stability was examined in the standard reaction mixture by measuring the

8 residual activity after incubation in GTA buffer for $1 \mathrm{~h}$ at $28^{\circ} \mathrm{C}$. The effects of

9 temperature on the activity were measured in the standard reaction mixture using

10 SACys as a substrate at $20-55^{\circ} \mathrm{C}$ for $30 \mathrm{~min}$. The temperature stability was examined

11 in the standard reaction mixture by measuring the residual activity after incubation at

12 each temperature for $1 \mathrm{~h}$. For the reparative laboratory scale productions of chiral

13 amino acid sulfoxides, the reaction mixture contained $50 \mathrm{mM}$ substrate, $100 \mathrm{mM}$

$14 \alpha$-ketoglutarate, $0.5 \mathrm{mM} \mathrm{FeSO} \cdot 7 \mathrm{H}_{2} \mathrm{O}, 2 \mathrm{mM}$ ascorbate, $1 \mathrm{mM}$ DTT, and $5 \mathrm{mg} / \mathrm{ml}(0.32$

$15 \mathrm{U} / \mathrm{ml}$ ) of IDO-catalyst in $1 \mathrm{ml}$ of a $50 \mathrm{mM}$ Tris/HCl buffer ( $\mathrm{pH} 7.0)$. The mixture was

16 slightly shaken at $28^{\circ} \mathrm{C}$. After $0,1,2$, and $4 \mathrm{~h}$ of incubation, $50 \mu$ laliquots were taken

17 and added to an equal volume of $20 \mathrm{mM}$ ethylenediamine- $N, N, N^{\prime}, N^{\prime}$-tetraacetic acid

18 (EDTA). The concentrations of amino acid sulfoxides produced were determined with

19 HPLC and ${ }^{1}$ H-NMR. All measurements were performed at least three times.

\section{4.6. Isolation of Oxidized Amino Acid Products}

The reaction mixtures were adjusted to $\mathrm{pH} 2.0$ with $1 \mathrm{M} \mathrm{HCl}$ and applied to

23 positive ion exchange resin (DOWEX 50W ×8; Dow Chemical, Midland, USA), which

24 was previously equilibrated with distilled water, and were eluted with $1 \mathrm{M} \mathrm{NH}_{3}$ solution. 
1 The fractions containing oxidized amino acid products were passed through negative

2 ion exchange resin (DOWEX $2 \times 8$ ), which was previously equilibrated with distilled

3 water, and were eluted with $1 \mathrm{M} \mathrm{HCl}$. The fractions containing the products were

4 combined, freeze-dried, and dissolved in $\mathrm{D}_{2} \mathrm{O}$. Isolated yields after purification were

$590,88,79,70$, and $65 \%$ for MetSO, EthSO, methiin, ethiin, and alliin, respectively.

6

$7 \quad 4.7$ L-Methionine (S)-sulfoxide [(+)-MetSO]

8

9

10

11

12

13

14

15

16

17

18

19

20

21

22

23

24

\subsection{L-Ethionine $(S)$-sulfoxide [(+)-EthSO]}

${ }^{1} \mathrm{H}$ NMR $\left(500 \mathrm{MHz}, \mathrm{D}_{2} \mathrm{O}\right) \delta: 1.30(\mathrm{t}, J=7.48 \mathrm{~Hz}, 3 \mathrm{H}), 2.28-2.32(\mathrm{~m}, 2 \mathrm{H})$,

2.86-2.93 (m, 1H), 2.95-3.01 (m, 2H), $3.88(\mathrm{t}, J=6.28 \mathrm{~Hz}, 1 \mathrm{H}) . \quad{ }^{13} \mathrm{C}$ NMR $(125 \mathrm{MHz}$,

$\left.\mathrm{D}_{2} \mathrm{O}\right) \delta: 6.58,24.59,45.08,46.25,54.04,173.82 . \quad[\alpha]_{\mathrm{D}}^{25}+30.9\left(\mathrm{c} 0.1, \mathrm{H}_{2} \mathrm{O}\right) . \quad$ ESI-MS

$(\mathrm{m} / \mathrm{z})=180[\mathrm{M}+\mathrm{H}]^{+}$

\section{9. $S$-Methyl-L-cysteine $(S)$-sulfoxide [(+)-Methiin]}

${ }^{1} \mathrm{H}$ NMR $\left(500 \mathrm{MHz}, \mathrm{D}_{2} \mathrm{O}\right) \delta: 2.82(\mathrm{~s}, 3 \mathrm{H}), 3.22(\mathrm{dd}, J=13.87,7.73 \mathrm{~Hz}, 1 \mathrm{H})$,

$3.47(\mathrm{dd}, J=13.93,5.98 \mathrm{~Hz}, 1 \mathrm{H}), 4.18(\mathrm{dd}, J=7.70,6.05 \mathrm{~Hz}, 1 \mathrm{H}) . \quad{ }^{13} \mathrm{C}$ NMR $(125$

$\left.\mathrm{MHz}, \mathrm{D}_{2} \mathrm{O}\right) \delta: 38.79,51.73,53.88,172.34 . \quad[\alpha]_{\mathrm{D}}^{25}+96.1\left(\mathrm{c} 0.1, \mathrm{H}_{2} \mathrm{O}\right) . \quad$ ESI-MS $(\mathrm{m} / \mathrm{z})$ $=152[\mathrm{M}+\mathrm{H}]^{+}$. 
$1 \quad$ 4.10. $S$-Ethyl-L-cysteine $(S)$-sulfoxide [(+)-Ethiin]

2

3

4

5

6

7

8

9

10

11

12

13

14

15

16

17

18

19

20

21 References

22

23

\section{References}

${ }^{1} \mathrm{H}$ NMR $\left(500 \mathrm{MHz}, \mathrm{D}_{2} \mathrm{O}\right) \delta: 1.30(\mathrm{t}, J=7.48 \mathrm{~Hz}, 3 \mathrm{H}), 2.91-2.97(\mathrm{~m}, 1 \mathrm{H})$,

$3.02-3.08(\mathrm{~m}, 1 \mathrm{H}), 3.19(\mathrm{dd}, J=13.95,7.75 \mathrm{~Hz}, 1 \mathrm{H}), 3.43(\mathrm{dd}, J=13.93,5.98 \mathrm{~Hz}, 1 \mathrm{H})$,

$4.20(\mathrm{dd}, J=7.40,6.35 \mathrm{~Hz}, 1 \mathrm{H}) .{ }^{13} \mathrm{C} \mathrm{NMR}\left(125 \mathrm{MHz}, \mathrm{D}_{2} \mathrm{O}\right) \delta: 6.42,46.52,51.05$,

51.70, 172.31. $[\alpha]_{\mathrm{D}}^{25}+40.0\left(\mathrm{c} 0.1, \mathrm{H}_{2} \mathrm{O}\right) . \quad$ ESI-MS $(\mathrm{m} / \mathrm{z})=166[\mathrm{M}+\mathrm{H}]^{+}$.

\subsection{1. $S$-Allyl-L-cysteine $(S)$-sulfoxide [(+)-Alliin]}

${ }^{1} \mathrm{H}$ NMR $\left(500 \mathrm{MHz}, \mathrm{D}_{2} \mathrm{O}\right) \delta: 3.21(\mathrm{dd}, J=13.95,7.65 \mathrm{~Hz}, 1 \mathrm{H}), 3.42(\mathrm{dd}, J=$ $13.90,6.30 \mathrm{~Hz}, 1 \mathrm{H}), 3.63(\mathrm{dd}, J=13.38,8.00 \mathrm{~Hz}, 1 \mathrm{H}), 3.84(\mathrm{dd}, J=13.45,6.90 \mathrm{~Hz}$ $1 \mathrm{H}), 4.18(\mathrm{dd}, J=7.45,6.38 \mathrm{~Hz}, 1 \mathrm{H}), 5.48(\mathrm{dd}, J=17.08,1.08 \mathrm{~Hz}, 1 \mathrm{H}), 5.54(\mathrm{~d}, J=$ $10.15 \mathrm{~Hz}, 1 \mathrm{H}), 5.87-5.95(\mathrm{~m}, 1 \mathrm{H}) . \quad{ }^{13} \mathrm{C} \mathrm{NMR}\left(125 \mathrm{MHz}, \mathrm{D}_{2} \mathrm{O}\right) \delta: 50.59,51.56,55.79$, 125.11, 125.94, 172.31. $[\alpha]_{\mathrm{D}}^{25}+31.3\left(\mathrm{c} 0.1, \mathrm{H}_{2} \mathrm{O}\right) . \quad$ ESI-MS $(\mathrm{m} / \mathrm{z})=178[\mathrm{M}+\mathrm{H}]^{+}$.

\section{Acknowledgements}

This work was partially supported by Grants-in-Aid for Scientific Research (no.

21780070 and 24688010 to M. Hibi, and no. 22658027 and 23248014 to J. Ogawa)

from the Ministry of Education, Culture, Sports, Science, and Technology of Japan.

1. Pellissier, H. Tetrahedron 2006, 62, 5559-5601. 
$1 \quad 2 . \quad$ Legros, J.; Dehli, J. R.; Bolm, C. Adv. Synth. Catal. 2005, 347, 19-31.

2 3. Lee, B. C.; Gladyshev, V. N. Free Radic. Biol. Med. 2011, 50, 221-227.

3 4. Rose, P.; Whiteman, M.; Moore, P. K.; Yi, Z. Z. Nat. Prod. Rep. 2005, 22,

4 351-368.

5 5. Stoewsand, G. S. Food Chem. Toxicol. 1995, 33, 537-543.

66 Kyung, K. H.; Han, D. C.; Fleming, H. P. J. Food Sci. 1997, 62, 406-409.

7 7. Itokawa, Y.; Inoue, K.; Sasagawa, S.; Fujiwara, M. J. Nutr. 1973, 103, 88-92.

8 8. Helen, A.; Krishnakumar, K.; Vijayammal, P. L.; Augusti, K. T. Pharmacology

9 2003, 67, 113-117.

10 9. Salman, H.; Bergman, M.; Bessler, H.; Punsky, I.; Djaldetti, M. Int. J. Immunopharmacol. 1999, 21, 589-597.

12 10. Augusti, K. T.; Sheela, C. G. Experientia 1996, 52, 115-119.

13 11. Kumari, K.; Augusti, K. T. J. Ethnopharmacol. 2007, 109, 367-371.

14 12. Ray, B.; Chauhan, N. B.; Lahiri, D. K. J Neurochem. 2011, 117, 388-402.

15 13. Komatsu, W.; Miura, Y.; Yagasaki, K. Lipids 1998, 33, 499-503.

16 14. Kubec, R.; Svobodova, M.; Velisek, J. J. Agric. Food Chem. 2000, 48, 428-33.

17 15. Wojaczynska, E.; Wojaczynski, J. Chem. Rev. 2010, 110, 4303-4356.

18 16. Bornscheuer, U. T.; Huisman, G. W.; Kazlauskas, R. J.; Lutz, S.; Moore, J. C.; 
Robins, K. Nature 2012, 485, 185-194.

2 17. Dembitsky, V. M. Tetrahedron 2003, 59, 4701-4720.

3 18. Holland, H. L. Nat. Prod. Rep. 2001, 18, 171-181.

4 19. Koch, I.; Keusgen, M. Pharmazie 1998, 53, 668-671.

5 20. Novick, R. M.; Elfarra, A. A. Drug Metab. Dispos. 2008, 36, 2468-2474.

6 21. Krause, R. J.; Lash, L. H.; Elfarra, A. A. J. Pharmacol. Exp. Ther. 2003, 304, 185-191.

8

22. Ripp, S. L.; Itagaki, K.; Philpot, R. M.; Elfarra, A. A. Arch. Biochem. Biophys.

9 1999, $367,322-332$.

23. Kodera, T.; Smirnov, S. V.; Samsonova, N. N.; Kozlov, Y. I.; Koyama, R.; Hibi, M.; Ogawa, J.; Yokozeki, K.; Shimizu, S. Biochem. Biophys. Res. Commun. 2009, 390, 506-510.

24. Ogawa, J.; Kodera, T.; Smirnov, S. V.; Hibi, M.; Samsonova, N. N.; Koyama, R.; Yamanaka, H.; Mano, J.; Kawashima, T.; Yokozeki, K.; Shimizu, S. Appl. Microbiol. Biotechnol. 2011, 89, 1929-1938.

25. Hibi, M.; Kawashima, T.; Kodera, T.; Smirnov, S. V.; Sokolov, P. M.; Sugiyama, M.; Shimizu, S.; Yokozeki, K.; Ogawa, J. Appl. Environ. Microbiol. 2011, 77, 6926-6930. 
1 26. Dever, J. T.; Elfarra, A. A. Drug Metab. Dispos. 2006, 34, 2036-43.

2 27. Holland, H. L.; Andreana, P. R.; Brown, F. M. Tetrahedron: Asymmetry 1999, 10, 2833-2843.

4 28. Kubec, R.; Dadakova, E. J. Chromatogr. A 2009, 1216, 6957-6963.

5 29. Kubec, R.; Svobodova, M.; Velisek, J. J. Chromatogr. A 1999, 862, 85-94.

6

7

8 


\section{Figure legends}

2

3 Figure 1. Asymmetric oxidation of sulfur-containing L-amino acids by IDO-catalyst.

4 Highly selective $(S)$-configured sulfoxidation of $S$-alkyl-L-homocysteins (a) and

$5 \quad S$-alkyl-L-cysteines (b).

6

$7 \quad$ Figure 2. Effects of $\mathrm{pH}$ and temperature on activity and stability of (+)-alliin

8 formation with IDO-catalyst. For the each reaction, $10 \mathrm{mM} \mathrm{SACys}$ and $0.13 \mathrm{U} / \mathrm{ml}$

9 IDO-catalyst was used. (a) The effects of $\mathrm{pH}$ on the activity and stability. (b) The

10 effects of temperature on the activity and stability.

11 Figure 3. Preparative laboratory productions of chiral amino acid sulfoxides.

12 For the each reaction, $50 \mathrm{mM}$ substrate and $0.32 \mathrm{U} / \mathrm{ml}$ IDO-catalyst was used. All

13 measurements were performed at least three times. (+)-MetSO (०), (+)-methiin $(\square)$,

14 (+)-ethiin $(\Delta),(+)$-alliin $(\diamond)$. 
1 Table 1. Bioconversion of sulfur-containing amino acids with IDO-catalyst

2

\begin{tabular}{ccccc}
\hline \multirow{2}{*}{ IDO Substrate } & $\begin{array}{c}\text { Derivatization method } \\
\text { for HPLC }\end{array}$ & Conversion (\%) & \multicolumn{2}{c}{ Product } \\
\cline { 4 - 5 } Met & FDAA & 100 & Configuration of sulfinyl group & de (\%) \\
\hline Eth & FDAA & 67 & $(S)$ & $>99$ \\
SMCys & Dns-Cl & 96 & $(S)$ & $>99$ \\
SECys & Dns-Cl & 100 & $(S)$ & 88 \\
SACys & Dns-Cl & 100 & $(S)$ & 91 \\
\hline
\end{tabular}

3

4 
1 Table 2. Preparative laboratory productions of chiral amino acid sulfoxides with

2 IDO-catalyst

3

\begin{tabular}{cccc}
\hline Sulfoxide & Produced $(\mathrm{mM})$ & Yield (\%) & de (\%) \\
\hline (+)-MetSo & 47 & 94 & $>99$ \\
(+)-Methiin & 32 & 64 & 93 \\
(+)-Ethiin & 43 & 86 & 95 \\
(+)-Alliin & 35 & 70 & 81 \\
\hline
\end{tabular}

4

5

6 


\section{$1 \quad$ Figure 1.}

2 (a)

3<smiles>CSCCC(N)C(=O)O</smiles>

Met

4

5

6

7

8

9

10

11

12

13

14

15

16

17

(b)<smiles>CCSC[C@H](N)C(=O)O</smiles>

SECys<smiles>CSCC(N)C(=O)O</smiles>

SMCys<smiles>C[SH](C)(=O)CCC(N)C(=O)O</smiles>

(+)-MetSO<smiles>CC[SH](C)(=O)CCC(N)C(=O)O</smiles>

(+)-EthSO<smiles>[2H][SH](C)(C)(C)CC(N)C(=O)O</smiles>

(+)-Methiin<smiles>C=CC[Si](C)([O])CC(N)C=O</smiles>

(+)-Alliin<smiles>CCS(=O)(=O)CC(N)C(=O)O</smiles>

(+)-Ethiin 


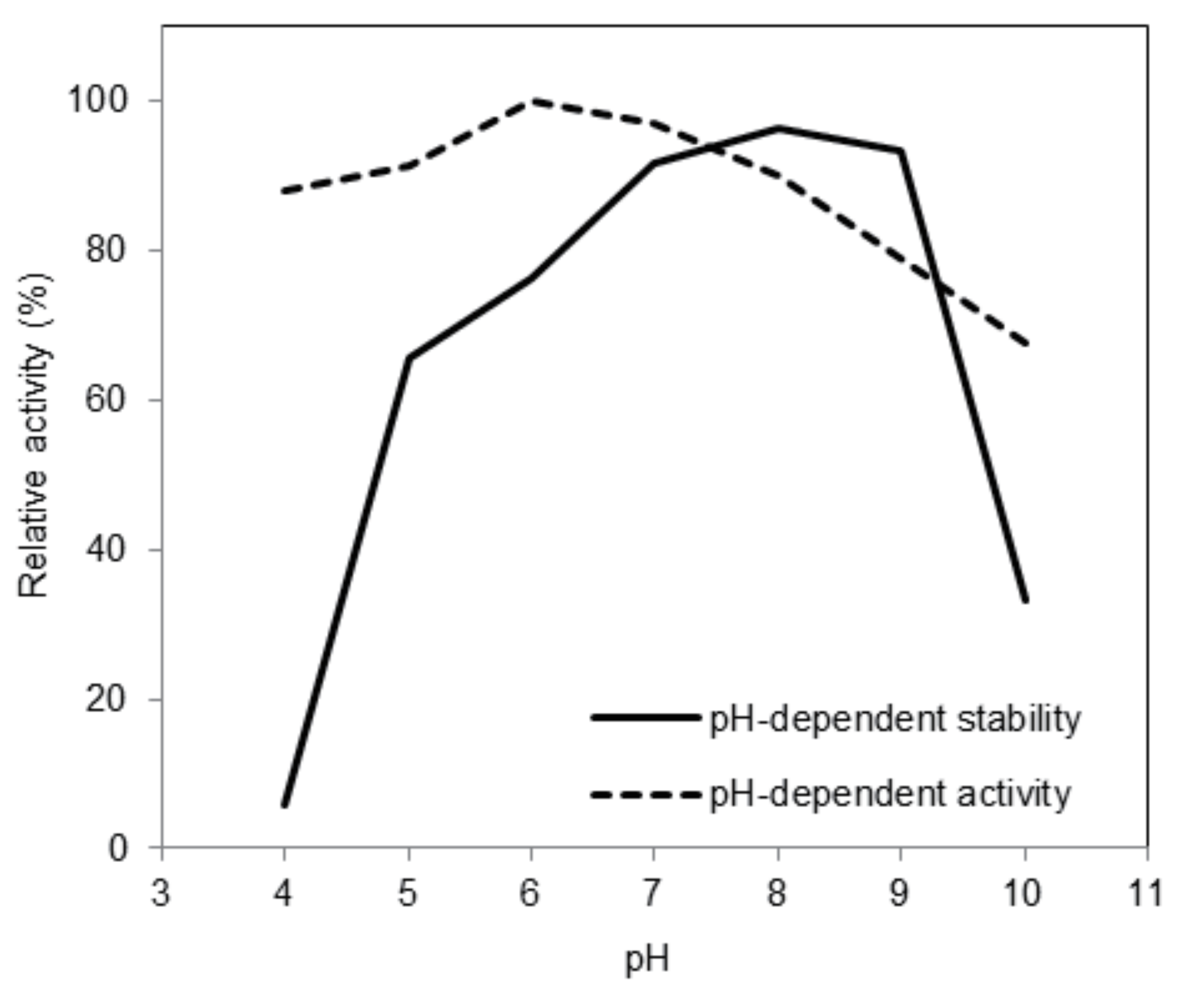

(n) 列 .

$-$
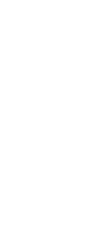

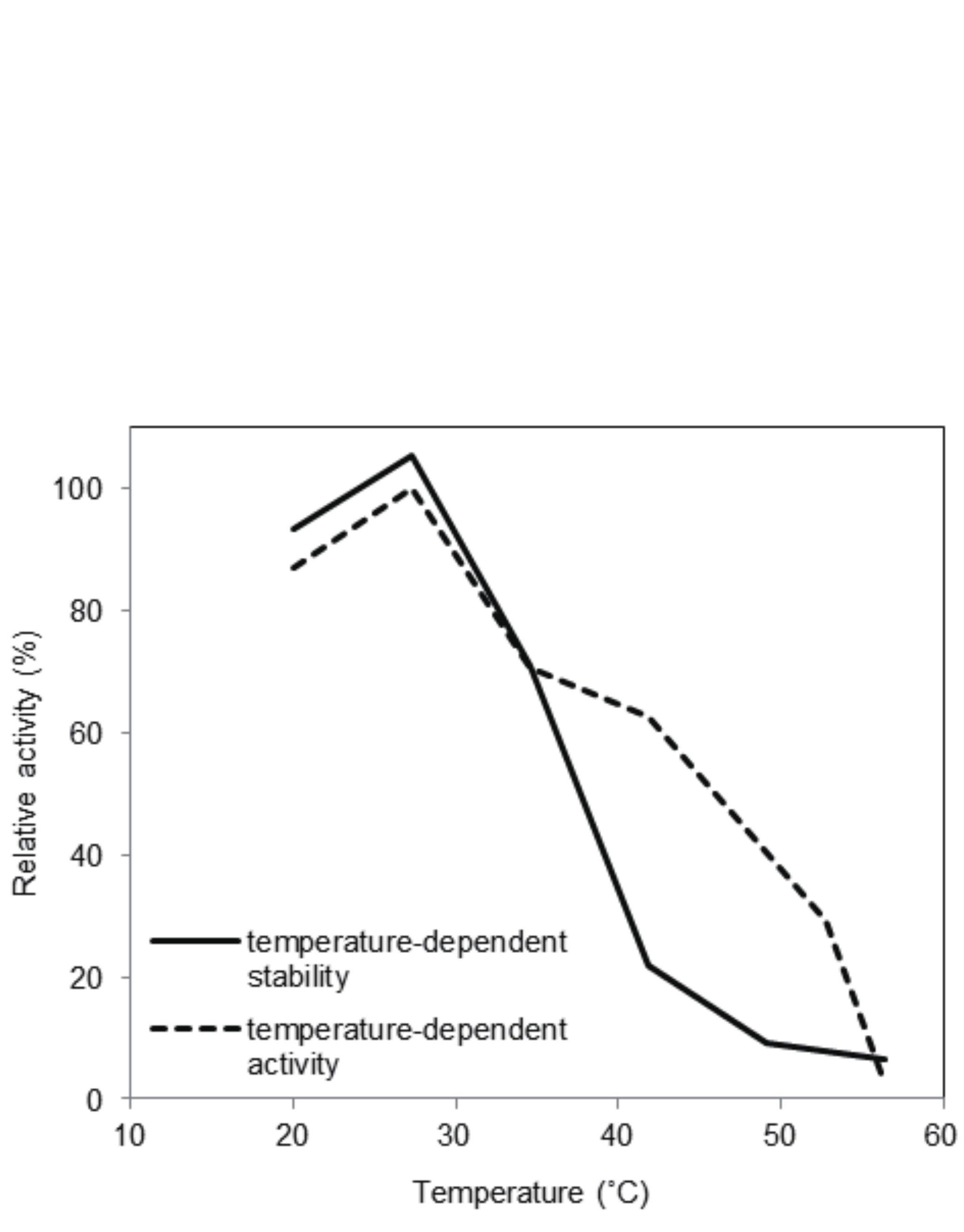

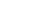




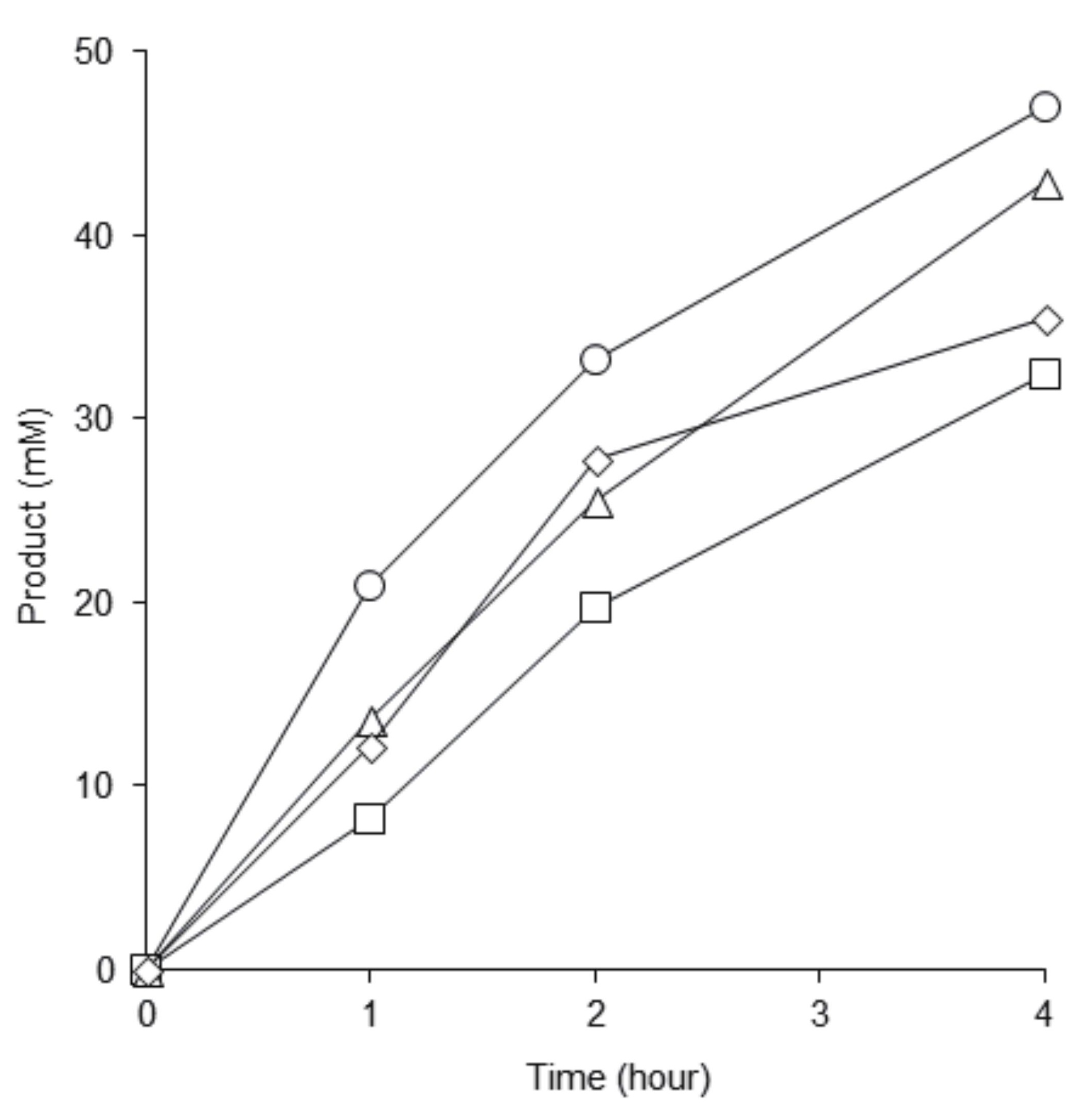


<smiles>C[SH](C)(=O)CC[C@H](N)C(=O)O</smiles>

L-Methionine $(S)$-sulfoxide

$[\alpha]_{\mathrm{D}}+67.3\left(\mathrm{c} 0.1, \mathrm{H}_{2} \mathrm{O}\right)$.

Absolute configuration: $(2 S,(\mathrm{~S}) S)$

Source of chirality: L-methionine, enzymatic sulfoxidation 
<smiles>CC[S@@](C)(=O)CC[C@H](N)C(=O)O</smiles>

L-Ethionine $(S)$-sulfoxide

$[\alpha]_{\mathrm{D}}+30.9\left(\mathrm{c} 0.1, \mathrm{H}_{2} \mathrm{O}\right)$.

Absolute configuration: $(2 S,(\mathrm{~S}) S)$

Source of chirality: L-ethionine, enzymatic sulfoxidation 
<smiles>C[S](C)(=O)C[C@H](N)C(=O)O</smiles>

$S$-Methyl-L-cysteine $(S)$-sulfoxide

$[\alpha]_{\mathrm{D}}+96.1\left(\mathrm{c} 0.1, \mathrm{H}_{2} \mathrm{O}\right)$.

Absolute configuration: $(2 S,(\mathrm{~S}) S)$

Source of chirality: $S$-methyl-L-cysteine, enzymatic sulfoxidation 
$\overbrace{\mathrm{O}}^{\prime \prime} \stackrel{\mathrm{NH}_{2}}{\mathrm{COOH}}$

$S$-Ethyl-L-cysteine $(S)$-sulfoxide

$[\alpha]_{\mathrm{D}}+40.0\left(\mathrm{c} 0.1, \mathrm{H}_{2} \mathrm{O}\right)$.

Absolute configuration: $(2 S,(\mathrm{~S}) S)$

Source of chirality: $S$-ethyl-L-cysteine, enzymatic sulfoxidation 
<smiles>C=CC[S@@](C)(=O)C[C@H](N)C(=O)O</smiles>

$S$-Allyl-L-cysteine $(S)$-sulfoxide

$[\alpha]_{\mathrm{D}}+31.3\left(\mathrm{c} 0.1, \mathrm{H}_{2} \mathrm{O}\right)$.

Absolute configuration: $(2 S,(\mathrm{~S}) S)$

Source of chirality: $S$-allyl-L-cysteine, enzymatic sulfoxidation 